\title{
Effect of sowing dates and phosphorus levels on growth and bulb production of Onion
}

Jawad Ali ${ }^{1}$, Abdurrab ${ }^{1}$, Haji Muhammad $^{2}$, Muhammad Ali ${ }^{1}$, Anwar Rashid $^{1}$, Abdul Shakoor ${ }^{3}$, Abid Khan ${ }^{4}$, Junaid Khan ${ }^{1}$, Abbas Jamal ${ }^{1}$ and Hamid Khan ${ }^{1}$

1. Department of Horticulture, The University of Agriculture Peshawar - Pakistan

2. Agriculture Extension Department Malakand University- Pakistan

3. Department of Mechanical Engineering, UET Peshawar- Pakistan

4. Agricultural Research Station Buner, Khyber Pakhtunkhwa- Pakistan

*Corresponding author's email: jwd.ali88@gmail.com

Citation

Jawad Ali, Abdurrab, Haji Muhammad, Muhammad Ali, Anwar Rashid, Abdul Shakoor, Abid Khan, Junaid Khan, Abbas Jamal and Hamid Khan. Effect of sowing dates and phosphorus levels on growth and bulb production of Onion. Pure and Applied Biology. Vol. 5, Issue 3, pp406-417. http://dx.doi.org/10.19045/bspab.2016.50053

Received: 08/02/2016

Revised: 16/04/2016

Accepted: 19/04/2016

Online First: 05/05/2016

\section{Abstract}

An experiment entitled "The effect of sowing dates and phosphorus levels on the growth and bulb production of onion" was conducted at Dargai with collaboration of Agriculture Extension Department Malakand Agency Pakistan in 2012. The experiment was laid out according to Randomized Complete Block Design (RCBD) with split plot arrangement. There were two factors i.e. sowing date and phosphorus levels. Sowing dates were assigned to main plots while different phosphorus levels were allotted to sub plots. The nursery of onions were raised on five different dates (26th October, 5th November, 15th November, 25th November and 5th December) 2012 and were treated with different levels of phosphorus $\left(0,60,90\right.$ and $\left.120 \mathrm{~kg} \mathrm{ha}^{-1}\right)$ at the time of transplantation. Increase in plant heights $(57.5 \mathrm{~cm})$, number of leaves $(9.0)$, leaf length $(46.4 \mathrm{~cm})$, leaf width $(1.0 \mathrm{~cm})$, bulb diameter $(4.9 \mathrm{~cm})$ average bulb weight $(84.8)$ and yield ton $\mathrm{ha}^{-1}$ (36) was observed when seeds were sown on 26th October while best results regarding plant height $(53 \mathrm{~cm})$, number of leaves $(8.3)$, leaf length $(41.1 \mathrm{~cm})$, leaf width $(0.8$ $\mathrm{cm})$, bulb diameter $(4.2 \mathrm{~cm})$ average bulb weight(58.2) and yield tons ha-1 (34.8) was observed with the application of $120 \mathrm{~kg}$ phosphorus $\mathrm{ha}^{-1}$. As onion sown on 26th October with the application of $120 \mathrm{~kg}$ phosphorus $\mathrm{ha}^{-1}$ resulted in overall best performance and hence recommended for onion bulbs production in Malakand region.

Keywords: Onion (Allium cepa L); Sowing dates; Phosphorus levels; Growth of onion bulb; Onion production

\section{Introduction}

Onion (Allium cepa L.) is an herbaceous, biennial, monocotyledonous. Onions were known to be grown about 5000 years ago.
Now a days there is more focus on increasing production of onions. The optimum use of fertilizer is the main factor of increasing production [1]. The production 
of onion is about 2.7 million in the world, producing 48 million tons each year. China, United States of America, Pakistan, Turkey and India are the main producing countries [2].

Onion is a cash crop and it is the most important bulbous vegetable crops. It is widely used as spice, salad and dressing. It is extensively cultivated in winter. It is recommended for persons suffering from high cholesterol, weakness, lethargy and lack of appetite. Onion is also used in Jaundice, bleeding, piles and prolepses and dog bites (Hydrophobia). The survey of literature indicates that very scanty work has been done on the effect of phosphorus on growth and yield on onion $[3,8]$.

Optimum fertilization is necessary for better production of crop. Phosphorus is important nutrient which enhances production. It also enhances plant growth and brings early maturity [1].

Phosphorus is important for root development and when unavailable plant growth is usually reduced. Its deficiency in onions reduces root and growth of leaf, size of bulb, yield and delay maturation. Onions growth can be enhanced by phosphorus fertilization where phosphorus is deficient in soils. Onions are more responsive to nutrient deficiencies than most crop plants because of their shallow root system hence respond well to optimum fertilizers. A number of production constraints are responsible for such reduced bulb yield of which lack of specific fertilizer recommendation for the area is in the top list $[4,12]$.

Onion is used as condiment in daily diet and helps to fight against blood and heart diseases. In Pakistan, onion is grown on an area of 105.6 thousand hectares with an annual production of 1488.5 thousand tonnes. Rapid increase in population is exerting more pressure on its demand. Onion being perishable commodity could not be stored for longer time. Less

availability of fresh onion increases its price from November to February in Punjab. Autumn crop was introduced by the Vegetable [17].

The sowing timing effects the vegetative growth of onion. Early sowing results in more vegetative growth having larger leaf area than the plants which have late sown. Sowing time effects bulb and seed production of onion production of onion which ultimately affects the yield of onion [19].

Hence, keeping the above points in view the present investigation will be undertaken at Dargai in collaboration with agriculture extension department dargai malakand agency to know the effect of sowing dates and phosphorus levels on the growth and bulb production of onion with the objectives to determine the optimum sowing date and phosphorus level for onion for better production.

\section{Materials and methods}

An experiment was conducted at Dargai with collaboration of Agriculture Extension Department Malakand Agency Pakistan. The experiment was laid out according to Randomized Complete Block Design (RCBD) with split plot arrangement with factors sowing dates and different phosphorus levels .The nursery of onions were raised in five different dates with the interval of ten days and was then transplanted after 35 days interval in the field. A transplanted plant were obtained from raised nursery. Nitrogen was applied at level $150 \mathrm{~kg} \mathrm{ha}^{-1}$ and potash was applied at $50 \mathrm{~kg} \mathrm{ha}-1$ to the field at time of transplantation. The plant to plant distance was 4 inches and row to row distance was 9 inches kept after transplant. An onion variety swat 3 was used in the experiment.

Factor A

(Sowing dates)

$\mathrm{S}_{1}$ 26/10/2011

$\mathrm{S}_{2} 5 / 11 / 2011$
Factor B (Phosphorus levels $\left.\mathrm{kg} \mathrm{ha}^{-1}\right)$ $\mathrm{P}_{1}=0$ (control) $\mathrm{P}_{2}=60$ 
$\mathrm{S}_{3} 15 / 11 / 2011 \quad \mathrm{P}_{3}=90$

$\mathrm{S}_{4} 25 / 11 / 2011 \quad \mathrm{P}_{4}=120$

$\mathrm{S}_{5}$ 5/12/2011

\section{Soil preparation and analysis}

Soil was ploughed up thoroughly and levelled. Farm yard manure was mixed to the soil. Urea $(46 \% \mathrm{~N})$ was used as nitrogen source and applied in split doses, one at the time of transplantation and other dose was after one month of transplantation. Sulphate of Potash $(50 \% \mathrm{~K})$ was used as potassium source and Single Super Phosphate (18\% P) as Phosphorus. Soil samples taken were analyzed and following results were obtained. Soil Analysis of the field is shown in Table 1.

Table 1. Soil analysis of the field

\begin{tabular}{|l|l|l|l|l|l|l|l|}
\hline Determination & $\begin{array}{l}\text { Nitrogen } \\
\mathbf{m g} / \mathbf{k g}\end{array}$ & $\begin{array}{l}\text { Bulk density } \\
\mathbf{g m} / \mathbf{c m} \text { cubic }\end{array}$ & $\mathbf{p H}$ & $\begin{array}{l}\text { EC } \\
\mathbf{d m s}^{-1}\end{array}$ & Texture & $\begin{array}{l}\text { Phosphor } \\
\mathbf{u s ~} \mathbf{m g} / \mathbf{k g}\end{array}$ & $\begin{array}{l}\text { Potassiu } \\
\mathbf{m ~ m g / k g}\end{array}$ \\
\hline Quality & 0.6 & 1.440 & 8.3 & 2.31 & $\begin{array}{l}\text { Sandy } \\
\text { clay loam }\end{array}$ & 0.20 & 0.25 \\
\hline
\end{tabular}

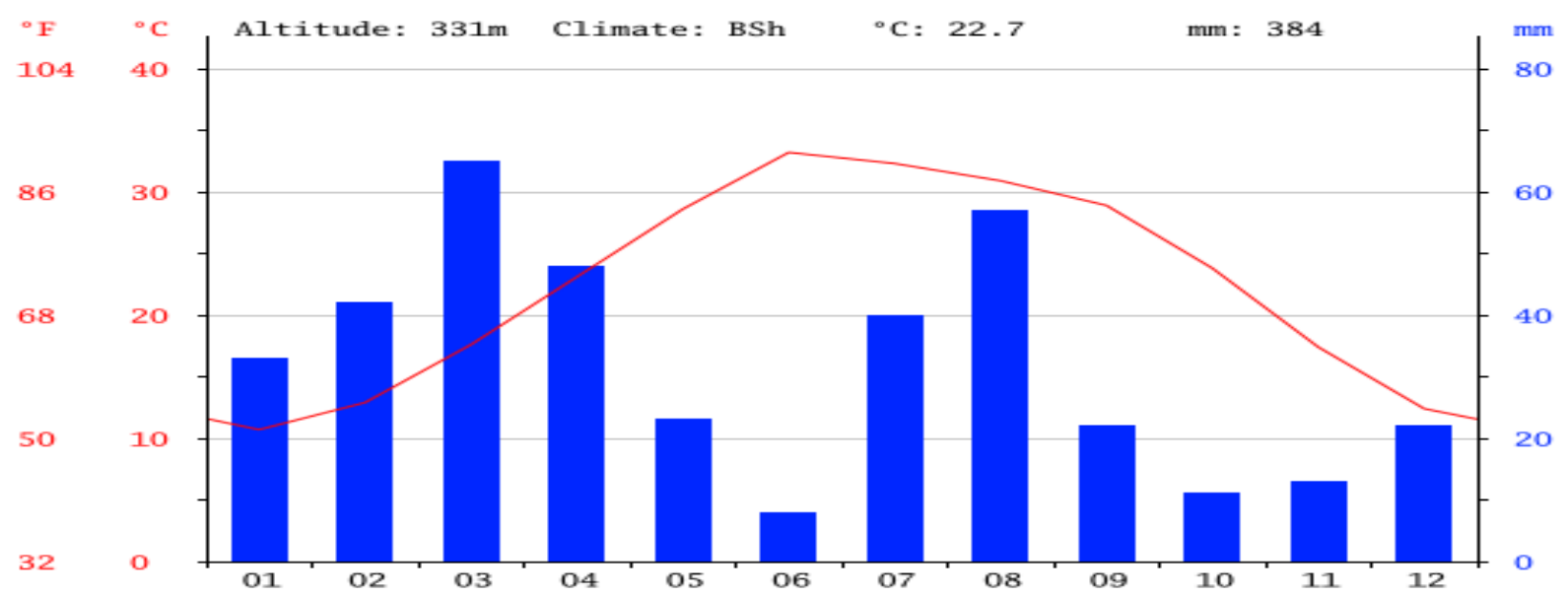

Figure 1. Rainfall Graph of Malakand Region in 2012

Rainfall graph of Malakand region for 2012 in given above, this graph clearly shows variation in rainfall of Malakand area in 2012 (Figure 1).

Parameters studied are given below:

\section{Number of leaves}

Total number of leaves originating from the bulb of twelve randomly selected plants was counted and average was calculated.

\section{Leaf length $(\mathbf{c m})$}

The length of leaves was measure with ruler originating from the bulb and average was calculated.

\section{Leaf width $(\mathbf{c m})$}

Leaf length was measured randomly from plants with the help of using ruler and its average was calculated.

\section{Plant height (cm)}

The plant height was noted with a ruler by measuring the distance from the soil to the plant tip.

\section{Bulb diameter $(\mathbf{c m})$}

The bulb diameter was measured with vernier calliper and average was calculated from randomly plants.

\section{Average bulb weight (g)}

Weight of bulbs was recorded by weighting the bulbs randomly in each replication and their average was calculated.

\section{Number of Bulbs kg-1}

Number of bulbs recorded after harvesting a crop from each replication and its average was calculated. 


\section{Yield Tons ha ${ }^{-1}$}

Bulb harvested from each treatment was weighted with the help of electronic balance and expressed in tonnes per hectare.

\section{Statistical procedure}

The data collected on different parameters was subjected to analysis of variance (ANOVA) technology to observe the difference, between different treatments as well as their interactions. In case where the difference was significant the mean was further assist for differences through least significant difference (LSD) test. Statistical computer software, MSTATC (Michigan state university, USA), was applied for computing both ANOVA and LSD [5].

\section{Results and discussion Number of leaves}

Analysis shows that number of leaves of onion was significantly affected by sowing dates, different phosphorus levels and their interaction (Table 2).

Maximum number of leaves (9.0) was recorded from the plants sown on 26th October followed by the plant sown on November (8.9) that was statistically similar with plants sown on 5 th November (9) and 26th October (8.3), respectively while the lowest number of leaves (4.5) was observed from the plants sown on 5th December. It might be due to the fact that the month of November is the best month for raising of

Table 2. No. of leaves plant ${ }^{-1}$, Leaf Length $(\mathrm{cm})$, Leaf width $(\mathrm{cm})$, Plant height $(\mathrm{cm})$ effected by sowing dates and phosphorus levels

\begin{tabular}{lcccc}
\hline & $\begin{array}{c}\text { No. of leaves } \\
\text { Plant }\end{array}$ & $\begin{array}{c}\text { Leaf Length } \\
(\mathbf{c m})\end{array}$ & $\begin{array}{c}\text { Leaf Width } \\
(\mathbf{c m})\end{array}$ & $\begin{array}{c}\text { Plant Height } \\
(\mathbf{c m})\end{array}$ \\
\hline \multicolumn{2}{l}{ Sowing Dates $(\mathbf{s})$} & & & \\
\hline $26^{\text {th }}$ Oct & $9.0 \mathrm{a}$ & $46.4 \mathrm{a}$ & $1.0 \mathrm{a}$ & $57.5 \mathrm{a}$ \\
$5^{\text {th }}$ Nov & $8.3 \mathrm{a}$ & $42.5 \mathrm{~b}$ & $.9 \mathrm{a}$ & $53.2 \mathrm{~b}$ \\
$15^{\text {th }}$ Nov & $8.9 \mathrm{a}$ & $41.5 \mathrm{~b}$ & $.7 \mathrm{~b}$ & $53.6 \mathrm{~b}$ \\
$25^{\text {th }}$ Nov & $5.1 \mathrm{~b}$ & $29.8 \mathrm{~d}$ & $.5 \mathrm{c}$ & $39.0 \mathrm{c}$ \\
$5^{\text {th }}$ Dec & $4.5 \mathrm{~b}$ & $3.0 \mathrm{c}$ & $.5 \mathrm{c}$ & $39.0 \mathrm{c}$ \\
\hline LSD (0.05) & 2.33 & 1.18 & 0.15 & 1.05 \\
\hline Phosphorus levels (p) & & & \\
\hline 0 & $5.7 \mathrm{c}$ & $33.8 \mathrm{c}$ & $.5 \mathrm{c}$ & $42.4 \mathrm{c}$ \\
60 & $7.1 \mathrm{~b}$ & $38.7 \mathrm{~b}$ & $.7 \mathrm{~b}$ & $45.8 \mathrm{~b}$ \\
90 & $7.5 \mathrm{ab}$ & $39.0 \mathrm{~b}$ & $.8 \mathrm{a}$ & $52.6 \mathrm{a}$ \\
120 & $8.3 \mathrm{a}$ & $41.4 \mathrm{a}$ & $.8 \mathrm{a}$ & $53.0 \mathrm{a}$ \\
\hline LSD (0.05) & 0.84 & 1.05 & .07 & 0.233 \\
\hline
\end{tabular}

Means followed by different letter(s) are significantly different at 5\% level of significance used LSD test nursery under climatic condition of Malakand for higher growth and yield components of onion. Similarly results were found by Cheema [6].

In case of phosphorus maximum number of leaves (8.3) were obtained at $120 \mathrm{~kg} \mathrm{ha}^{-1}$ followed by number of leaves (7.5) recorded at the application of $90 \mathrm{~kg} \mathrm{ha}^{-1}$ while the lowest number of leaves (5.7) was observed in control. It might be due to the fact that the phosphorus is an essential component of nucleic acids, phospholipids and some amino acids and absorbed phosphorus helped a direct stimulation of cellular activity in roots and leaves, it is useful for the process of cell division and meristematic growth and the net assimilation rate of phosphorus fed plants were accelerated by their increased content and the absorbed phosphorus helped the formation of food reserves due to higher photosynthetic activity so therefore increases of number of leaves. Similar results were found by $[3,11]$.

The results of interaction between sowing dates and phosphorus showed that more number of leaves (12.0) was observed in the plants sown on 26th October treated with 120 $\mathrm{kg} \mathrm{P} \mathrm{ha}{ }^{-1}$ while lowest number of leaves (4.0) was observed in the plant sown on 26th October without phosphorus. Interaction has been shown in Figure 2. 


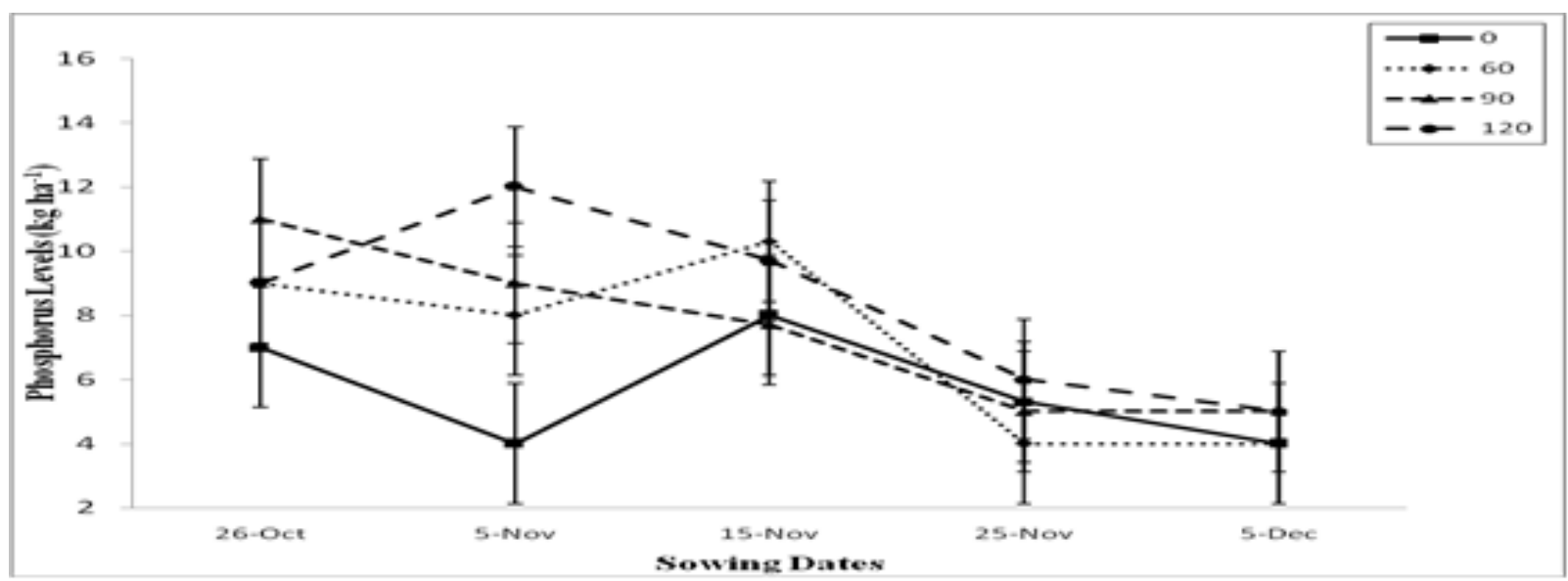

Figure 2. Effect of phosphorus levels and different sowing dates on number of leaves

\section{Leaf Length (cm)}

Leaf length was significantly affected by sowing dates and phosphorus similarly interaction between sowing dates and phosphorus was also found significant (Table 2).

Maximum leaf length $(46.4 \mathrm{~cm})$ was recorded from the plants sown on 26th October which was statistically different from the rest of the treatments followed by the plant sown on 15 th November $(42.5 \mathrm{~cm})$ while the lowest leaf length $(29.8 \mathrm{~cm})$ was observed in the plants sown on 25th November. It might be due to the month of November is suitable for onion growing under climatic condition of Malakand for higher growth and yield components of onion. Similar, results were found by [7].

In case of phosphorus maximum leaf length $(41.4 \mathrm{~cm})$ was recorded in plants treated with $120 \mathrm{~kg} \mathrm{ha}^{-1}$ followed by plants $(39 \mathrm{~cm})$ treated with $90 \mathrm{~kg} \mathrm{ha}^{-1}$ while the lowest leaf length $(33.8 \mathrm{~cm})$ was obtained in control treatment. It might be due to the fact that the phosphorus is an essential component of nucleic acids, phospholipids, and some amino acids and absorbed phosphorus helped a direct stimulation of cellular activity in roots and leaves, it is useful for the process of cell division and meristematic growth and the net assimilation rate of phosphorus fed plants were accelerated by their increased content and the absorbed phosphorus helped the formation of food reserves due to higher photosynthetic activity so therefore increases of length . Similar results were found by $[\mathbf{8}, \mathbf{1 8}]$.

In case of interaction between sowing dates and phosphorus the maximum leaf length $(51.0 \mathrm{~cm})$ was observed in the plants sown on 26th October supplied with $120 \mathrm{~kg} \mathrm{P}^{-1}$ while lowest leaf length $(27.0 \mathrm{~cm})$ was observed in the untreated plants, sown on 25th November. Interaction has been shown in Figure 3.

\section{Leaf width $(\mathbf{c m})$}

Leaf width was significantly affected by sowing dates and phosphorus levels similarly interaction between sowing dates and phosphorus levels was also found significant (Table 2).

Wider leaf $(1 \mathrm{~cm})$ was recorded from the plant sown on $26^{\text {th }}$ October followed by the leaf width $(0.9 \mathrm{~cm})$ recorded from the plant sown on $5^{\text {th }}$ November while the lowest leaf width $(0.5 \mathrm{~cm})$ was observed from the plants sown on $25^{\text {th }}$ November and $5^{\text {th }}$ December which were statistically same . It might be due to the month of November is the best sowing dates for onion for nursery sowing under climatic condition of Malakand for 
higher growth and yield components of onion. Similarly, results were found by [6]. As concerned phosphorus levels, plants supplied with $120 \mathrm{~kg} \mathrm{P} \mathrm{ha}^{-1}$ and $90 \mathrm{~kg} \mathrm{P} \mathrm{ha}^{-1}$ gave more leaf width $(0.8 \mathrm{~cm})$, followed by $60 \mathrm{~kg} \mathrm{P} \mathrm{ha}^{-1}(0.7 \mathrm{~cm})$ while the lowest leaf width $(0.5 \mathrm{~cm})$ was observed in untreated plants with phosphorus. It might be due to the fact that the phosphorus is an essential component of nucleic acids, phospholipids and some amino acids and absorbed phosphorus helped a direct stimulation of cellular activity in roots and leaves, it is useful for the process of cell division and meristematic growth and the net assimilation rate of phosphorus fed plants were accelerated by their increased content and the absorbed phosphorus helped the formation of food reserves due to higher photosynthetic activity so therefore increases of leaf width. Similar results were found by [9].

In case of interaction between sowing dates and phosphorus the maximum leaf weight $(1.3 \mathrm{~cm})$ was observed in the plant sown on 26th October treated with $120 \mathrm{~kg} \mathrm{P} \mathrm{ha}{ }^{-1}$ while $5^{\text {th }}$ December plantation when treated with $90120 \mathrm{~kg} \mathrm{P}^{-1}$ gave less leaf width $(0.4 \mathrm{~cm})$.Interaction has been shown in Figure 4.

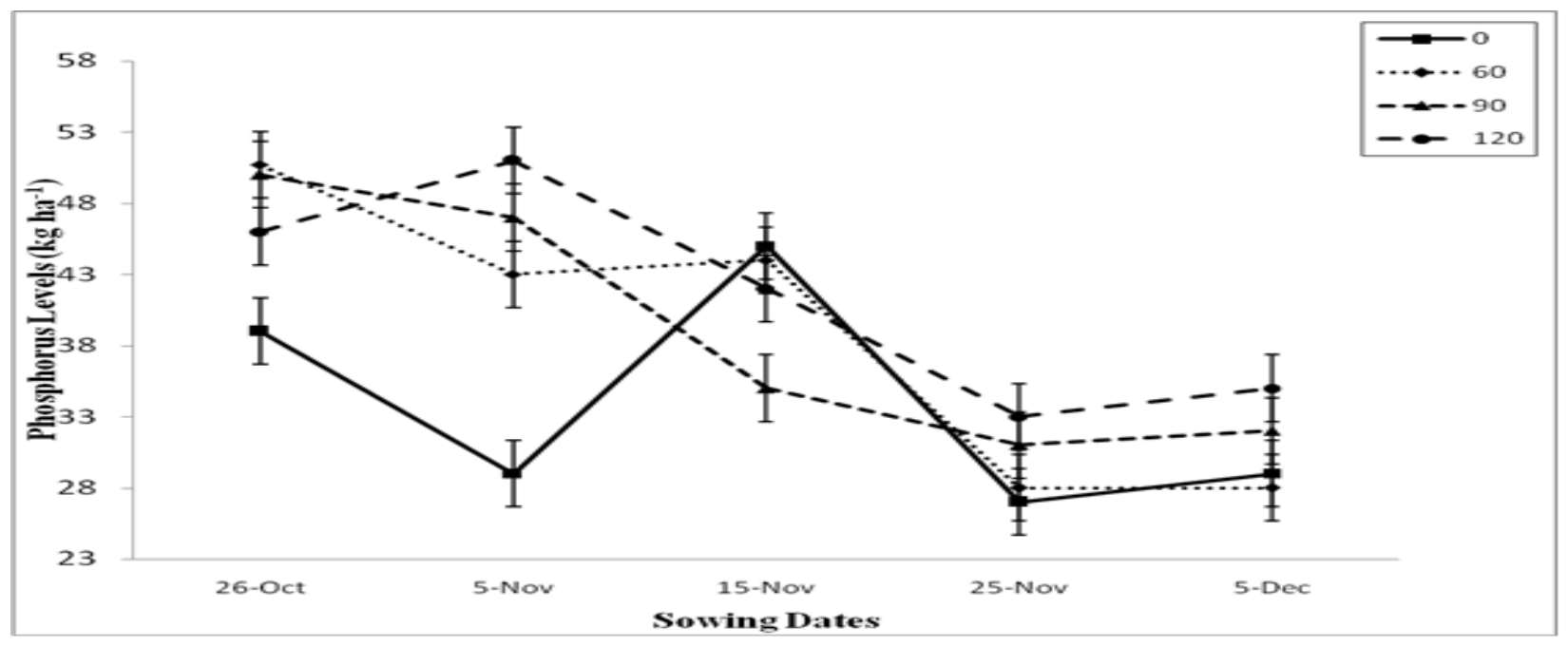

Figure 3. Effect of phosphorus levels and different sowing dates on leaf length

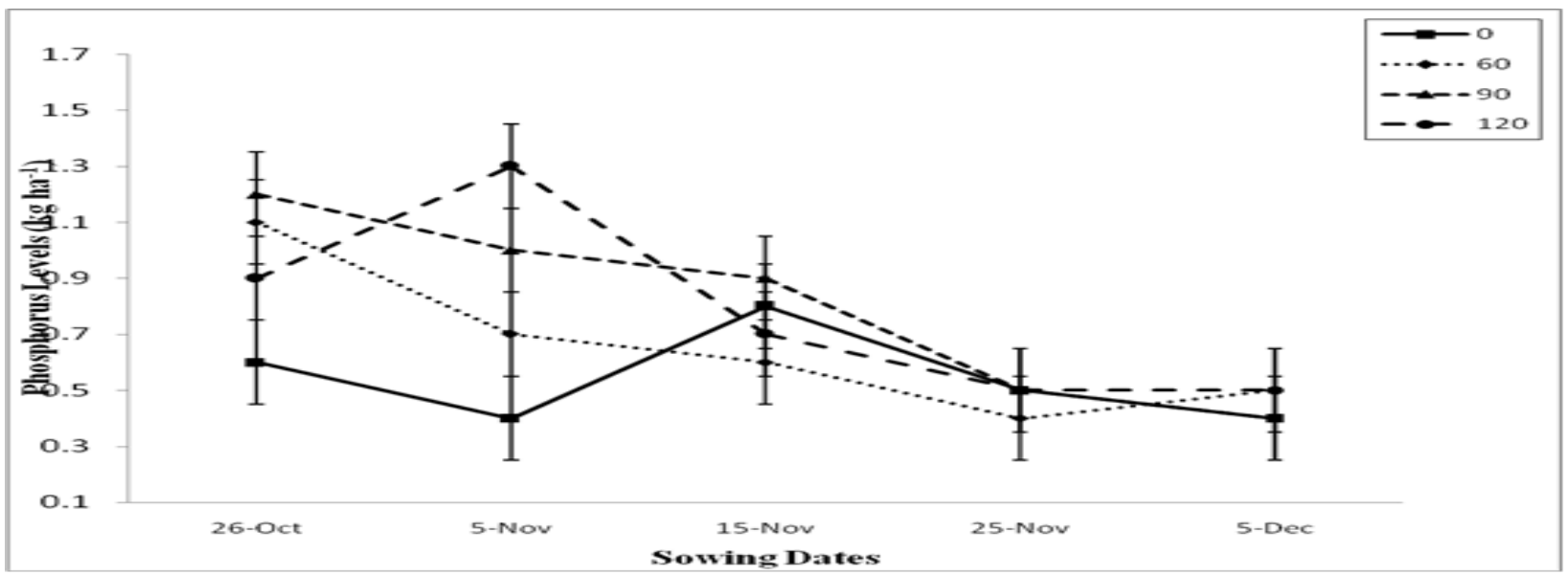

Figure 4. Effect of phosphorus levels and different sowing dates on leaf width 


\section{Plant Height (cm)}

Plant height was significantly affected by sowing dates and phosphorus level, similarly interaction between sowing dates and phosphorus were found significant (Table 2). More plant height $(57.2 \mathrm{~cm})$ was recorded from the plant sown on $26^{\text {th }}$ October followed by $(53.6 \mathrm{~cm})$ on $15^{\text {th }}$ November while the lowest plant height (39 $\mathrm{cm}$ ) was observed from the plants sown on $25^{\text {th }}$ November and $5^{\text {th }}$ December. It might be due to the fact that the month of November is the best sowing date for onion for nursery sowing under climatic conditions of Malakand for higher growth and yield components of onion. Similar results were found by [10].

In case of phosphorus higher plant height $(53.0 \mathrm{~cm})$ was recorded at the application of $120 \mathrm{~kg} \mathrm{ha}^{-1}$ which was related with plant height $(52.6 \mathrm{~cm})$ by the application of $90 \mathrm{~kg}$ $\mathrm{ha}^{-1}$ while the lowest height of plant (42.4 $\mathrm{cm}$ ) was noted in control treatment. It might be due to the fact that the phosphorus is an essential component of nucleic acids, phospholipids and some amino acids and absorbed phosphorus helped a direct stimulation of cellular activity in roots and leaves, it is useful for the process of cell division and meristematic growth and the net assimilation rate of phosphorus fed plants were accelerated by their increased content and the absorbed phosphorus helped the formation of food reserves due to higher photosynthetic activity. Therefore, due to accelerated growth of plant, increase in plant height was observed. Similar results were found by [11].

As concerned interaction maximum plant height $(62.7 \mathrm{~cm})$ was obtained in the plants sown on 26th October applied with $120 \mathrm{~kg} \mathrm{P}$ $\mathrm{ha}^{-1}$ while lowest height of plant $(33 \mathrm{~cm})$ was obtained in the plant sown on 25th November in untreated plants with phosphorus. Interaction has shown in Figure 5 .

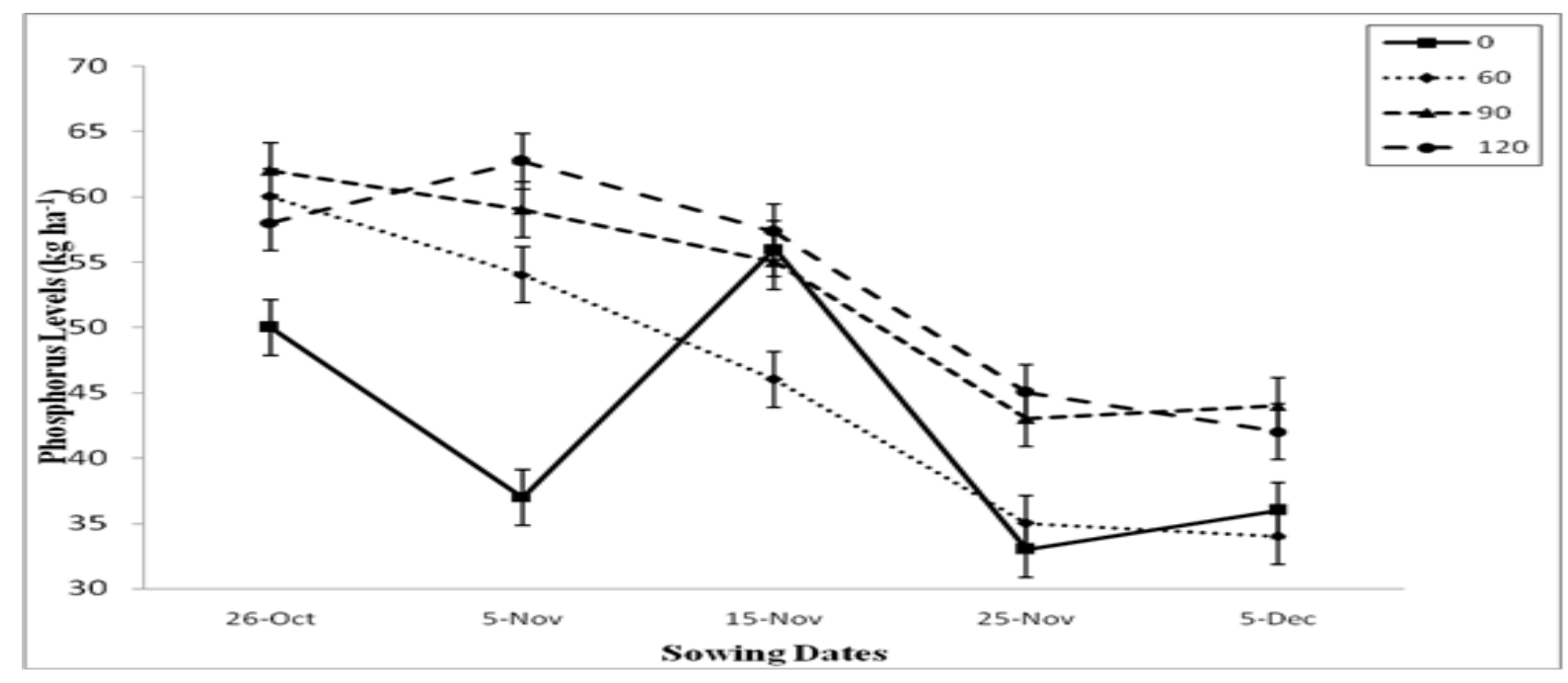

Figure 5. Effect of phosphorus levels and different sowing dates on plant height

\section{Bulb Diameter (cm)}

Bulb diameter was significantly affected by sowing dates and phosphorus levels similarly interaction between sowing dates and phosphorus levels was also found significant (Table 3).
Maximum bulb diameter $(4.9 \mathrm{~cm})$ was recorded from plants planted on 26th October followed by bulb diameter $(4.5 \mathrm{~cm})$ recorded from the plant sown on 5th November while the lowest bulb diameter $(3.0 \mathrm{~cm})$ was observed from the plant sown on 25th November and 5th December 
which were statistically same. It might be due to the month of November is the best sowing dates for onion for nursery sowing under climatic condition of Malakand for higher growth and yield components of onion. Similarly, results were found by [12]. In case of phosphorus maximum bulb diameter $(4.2 \mathrm{~cm})$ was obtained by the application of $120 \mathrm{~kg} \mathrm{P} \mathrm{ha-1}$ followed by bulb diameter $(4.1 \mathrm{~cm})$ recorded by the application of $90 \mathrm{~kg} \mathrm{P} \mathrm{ha}{ }^{-1}$ which was related with bulb diameter $(4 \mathrm{~cm})$ recorded by the application of $60 \mathrm{~kg} \mathrm{P} \mathrm{ha}^{-1}$ while the lowest leaf width $(3.4 \mathrm{~cm})$ was observed at control. It might be due to the fact that the phosphorus improved the carbohydrate content of the plants and it extended root growth, which ultimately increased the blub size. Similar results were found by [13].

In case of interaction between sowing dates and phosphorus the maximum bulb diameter $(5.5 \mathrm{~cm})$ was observed in the plants sown on 26th October and $5^{\text {th }}$ November treated with $120 \mathrm{~kg} \mathrm{P} \mathrm{ha}^{-1}$ and $90 \mathrm{~kg} \mathrm{P} \mathrm{ha}^{-1}$ while lowest bulb diameter $(2.5 \mathrm{~cm})$ was observed from the plants sown on $25^{\text {th }}$ November untreated with phosphorus. Interaction has shown in Figure 6.

Table 3. Bulb Diameter (cm), Number of bulbs kg-1, Average Bulb weight (g), Total Yield ha $^{-1}$ (tons) effected by sowing dates and phosphorus levels

\begin{tabular}{|c|c|c|c|c|}
\hline \multicolumn{2}{|c|}{$\begin{array}{l}\text { Bulb Diameter } \\
\text { (cm) }\end{array}$} & $\begin{array}{l}\text { Number of } \\
\text { bulbs kg-1 }\end{array}$ & $\begin{array}{l}\text { Average Bulb } \\
\text { weight (g) }\end{array}$ & $\begin{array}{l}\text { Total Yield } \\
\text { ha }^{-1} \text { (tons) }\end{array}$ \\
\hline \multicolumn{5}{|c|}{ Sowing Dates (s) } \\
\hline $26^{\text {th }}$ Oct & $4.9 \mathrm{a}$ & $21.5 b$ & $84.8 \mathrm{a}$ & $36.0 \mathrm{a}$ \\
\hline $5^{\text {th }}$ Nov & $4.5 b$ & $21.2 b$ & $77.2 \mathrm{~b}$ & $34.8 \mathrm{~b}$ \\
\hline $15^{\text {th }}$ Nov & $4.4 \mathrm{~b}$ & $18.8 \mathrm{c}$ & $58.2 \mathrm{c}$ & $34.8 \mathrm{~b}$ \\
\hline $25^{\text {th }}$ Nov & $3.0 \mathrm{c}$ & $24.3 \mathrm{a}$ & $22.8 \mathrm{~d}$ & $32.4 \mathrm{c}$ \\
\hline $5^{\text {th }}$ Dec & $3.0 \mathrm{c}$ & $20.5 b c$ & $19.1 \mathrm{e}$ & $32.4 \mathrm{c}$ \\
\hline LSD (0.05) & .13 & 1.87 & 0.99 & 0.24 \\
\hline \multicolumn{5}{|c|}{ Phosphorus levels (p) } \\
\hline 0 & $3.4 \mathrm{~d}$ & $24.4 \mathrm{a}$ & $47.3 c$ & $33.0 \mathrm{c}$ \\
\hline 60 & $4.0 \mathrm{c}$ & $21.7 b$ & $49.1 \mathrm{c}$ & $33.9 b$ \\
\hline 90 & $4.1 b$ & $18.0 \mathrm{c}$ & $53.1 b$ & $34.7 \mathrm{a}$ \\
\hline 120 & $4.2 \mathrm{a}$ & $20.9 b$ & $58.2 \mathrm{a}$ & $34.8 \mathrm{a}$ \\
\hline LSD (0.05) & 0.11 & 1.27 & 0.69 & 0.14 \\
\hline
\end{tabular}

Means followed by different letter(s) are significantly different at $5 \%$ level of significance used LSD test

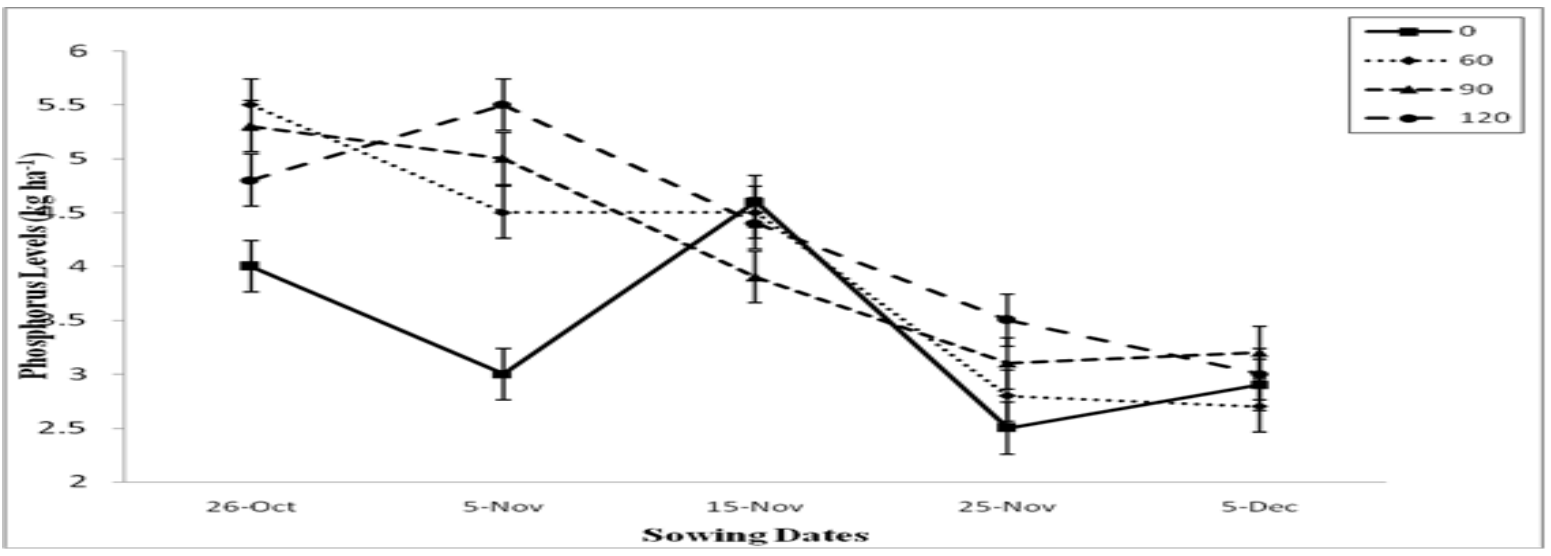

Figure 6. Effect of phosphorus levels and different sowing dates on bulb diameter 


\section{Number of bulbs $\mathbf{~ k g}^{-1}$}

Number of bulbs $\mathrm{kg}^{-1}$ was significantly affected by sowing dates and phosphorus levels similarly interaction between sowing dates and phosphorus levels was also found significant (Table 3 ).

Maximum number of bulbs $\mathrm{kg}^{-1}$ (24.5) were recorded from plants sown on 25th November followed by number of bulbs $\mathrm{kg}^{-1}$ (21.5) recorded from the plant sown on 5th November while the lowest number of bulbs $\mathrm{kg}^{-1}$ (18.8) were observed from the plant sown on 15 th November .It might be due to the month of November is the best sowing dates for onion for nursery sowing under climatic condition of Malakand for higher growth and yield components of onion. Similarly, results were found by [6].

In case of phosphorus maximum number of bulbs $\mathrm{kg}^{-1}$ (24.4) was recorded in plants untreated with phosphorus followed number of bulbs $\mathrm{kg}^{-1}$ (22.1) by the plants supplied with $60 \mathrm{~kg} \mathrm{P} \mathrm{ha}^{-1}$ while the lowest number of bulbs $\mathrm{kg}^{-1}$ (18) were observed by the application $90 \mathrm{~kg} \mathrm{P} \mathrm{ha}^{-1}$. It might be due to the fact that the phosphorus improved the carbohydrate content of the plants and it extended root growth, which ultimately increased the number of blub and blub size so increase bulb weight. Similar results were found by [3].

In case of interaction between sowing dates and phosphorus levels the maximum number of bulb $\mathrm{kg}^{-1}$ (37) were observed from the plant sown on $25^{\text {th }}$ November sowing treated with $60 \mathrm{~kg} \mathrm{P} \mathrm{ha}^{-1}$ while lowest number of bulb $\mathrm{kg}^{-1}$ (13) were observed by the plant sown on $5^{\text {th }}$ December and supplied with 90 $\mathrm{kg} \mathrm{P} \mathrm{ha}{ }^{-1}$. Interaction has been shown Figure 7.

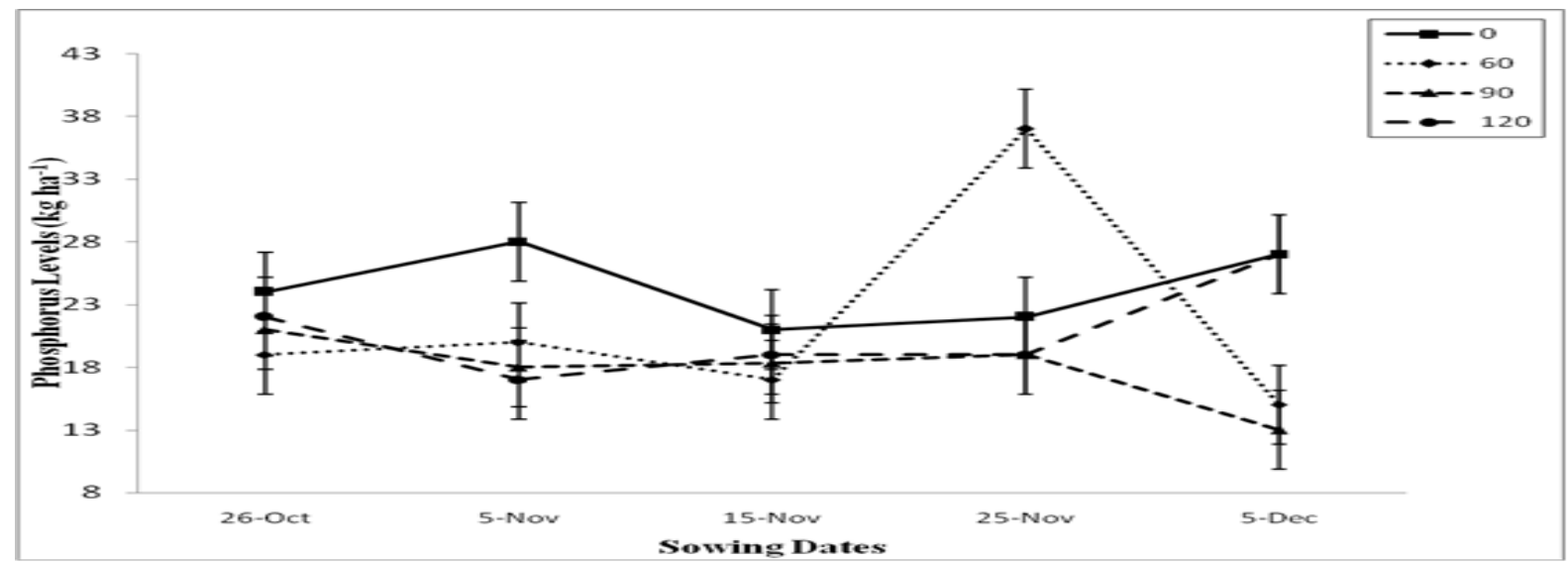

Figure 7. Effect of phosphorus levels and different sowing no of bulbs $\mathrm{kg}^{-1} \mathrm{hieght}^{-}$

\section{Average bulb weight (g)}

Average bulb weight was significantly affected by sowing dates and phosphorus levels similarly interaction between sowing dates and phosphorus levels was also found significant (Table 3 ).

Maximum average bulb weight (84.8 g) was recorded from the plant sown on $15^{\text {th }}$ November followed by (77.2g) recorded from the plant sown on $5^{\text {th }}$ November while the lowest average bulb weight (19.1g) was observed in plants sown on $5^{\text {th }}$ December. It might be due to the month of November is the best sowing dates for onion for nursery sowing under climatic condition of Malakand for higher growth and yield components of onion. Similarly results were found by [13].

In case of phosphorus maximum average bulb weight $(58.2 \mathrm{~g})$ was obtained by the application of $120 \mathrm{~kg} \mathrm{ha}^{-1}$ followed by (53.1g) by $\mathrm{P}$ at $90 \mathrm{~kg} \mathrm{ha}^{-1}$ while the lowest average bulb weight (49.1gm) was observed in plants untreated with phosphorus. It might 
be due to the fact that the phosphorus improved the carbohydrate content of the plants and it extended root growth, which ultimately increased the number of blub and blub size so increase of size bulb weight was also increase. Similar results were found by [16].
In case of interaction between sowing dates and phosphorus levels maximum average bulb weight $(92 \mathrm{~g})$ was observed in plants sown on 15th November untreated with phosphorus while lowest average bulb weight $(12.2 \mathrm{gm})$ was observed in plant sown on $5^{\text {th }}$ December supplied with $120 \mathrm{~kg} \mathrm{P}$ ha $^{-}$ ${ }^{1}$. Interaction has been shown Figure 8.

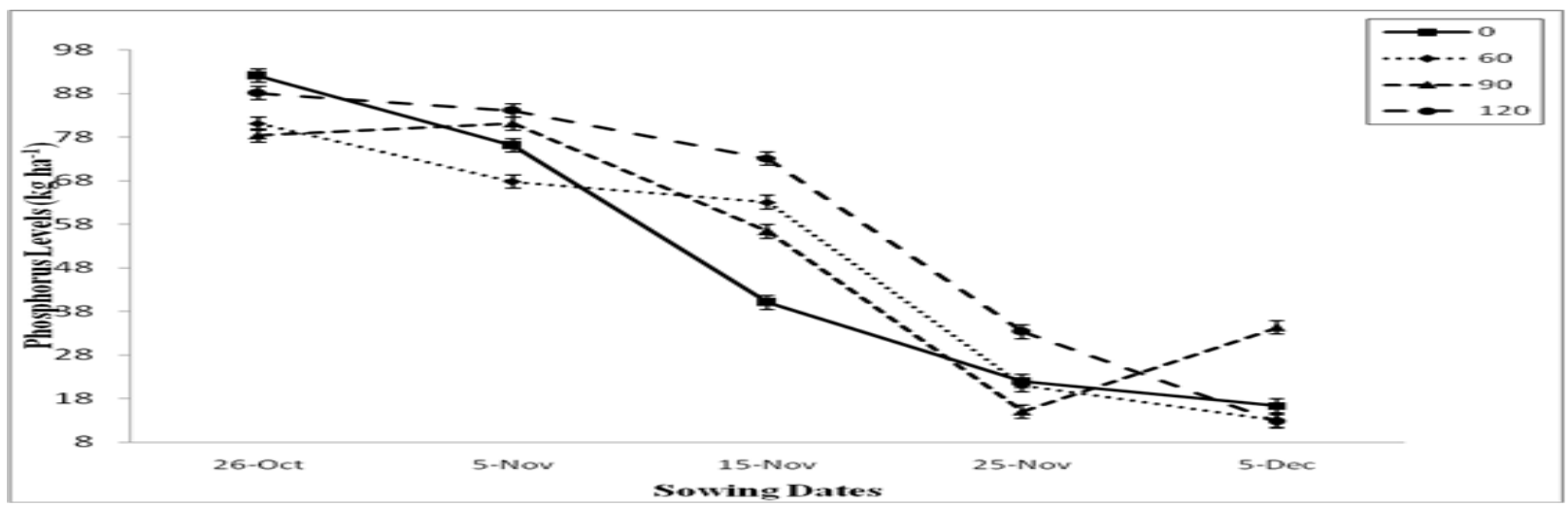

Figure 8. Effect of phosphorus levels and different sowing no of average bulb weight

\section{Yield tons $\mathrm{ha}^{-1}$ :}

Yield tons ha ${ }^{-1}$ was significantly affected by sowing dates and phosphorus levels similarly interaction between sowing dates and phosphorus levels was also found significant (Table 3).

The highest yield tons $\mathrm{ha}^{-1}$ (36 tonnes) was recorded from plants sown on 26th October followed by (34.8 tonnes) and (34.7 tonnes) from the plants sown on 5th November and 15th November respectively, which are at par with each other while the lowest yield ton $\mathrm{ha}^{-1}$ (32.4 tonnes) was observed from the plants sown on $5^{\text {th }}$ December and 25th November which are also statistically same. It might be due to the month of November is the best sowing dates for onion for nursery sowing under climatic condition of Malakand for higher growth and yield components of onion. Similarly results were found by [14].
In case of phosphorus maximum yield $\mathrm{kg}$ $\mathrm{hac}^{-1}$ (34.8 tonnes) was obtained by the application of $120 \mathrm{~kg} \mathrm{P}^{-1}$ followed by (34.7 tonnes) with the application of $90 \mathrm{~kg} \mathrm{P}$ $\mathrm{ha}^{-1}$ while the lowest yield tons $\mathrm{ha}^{-1}$ ( 33 tonnes) was observed in plants untreated with phosphorus. It might be due to the fact that the phosphorus improved the carbohydrate content of the plants and it extended root growth, which ultimately increased the number of blub and blub size so increase yield tones $\mathrm{ha}^{-1}$. Similar results were found by [15].

In case of interaction between sowing dates and phosphorus the maximum yield (36.6 tonnes) was observed in plants sown on 26th October and treated with $120 \mathrm{~kg} \mathrm{P} \mathrm{ha}^{-1}$ while lowest yield (31.3 tonnes) was observed from the plants sown on $25^{\text {th }}$ November untreated with phosphorus .Interaction has been shown Figure 9. 


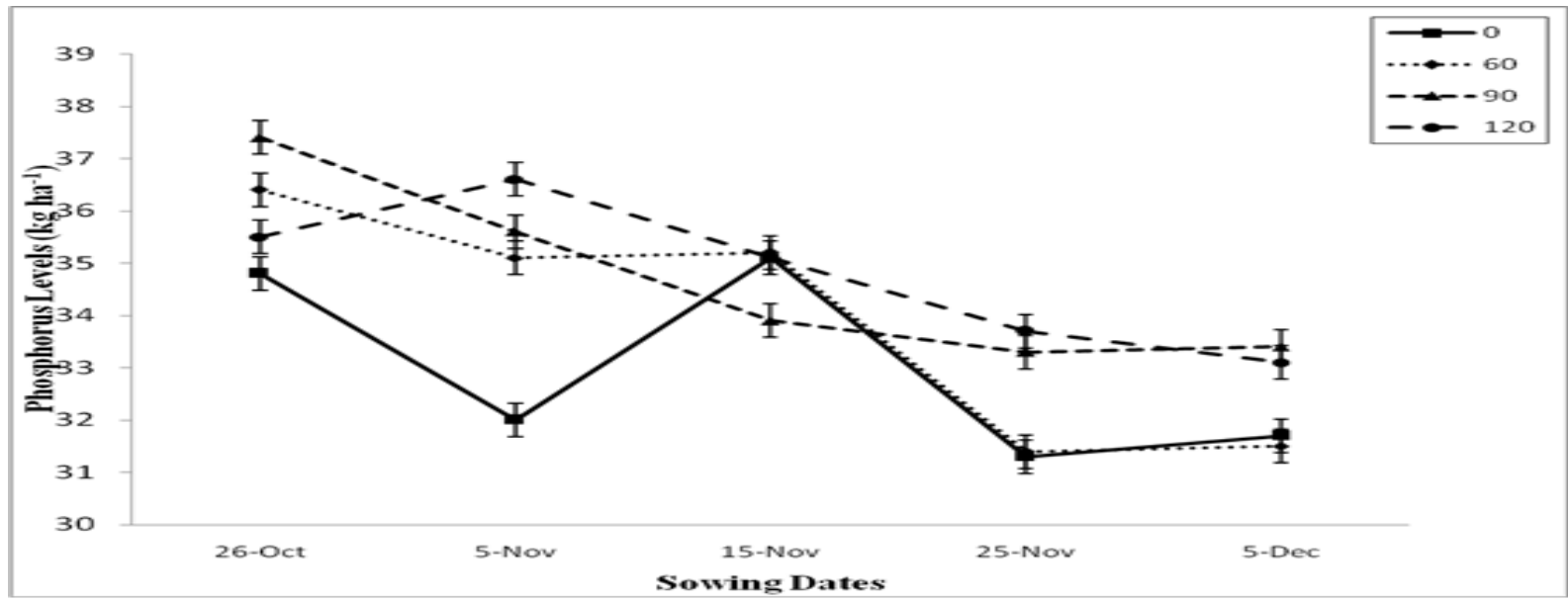

Figure 9. Effect of phosphorus levels and different sowing no of average yield ton ha $\mathbf{h}^{-1}$

\section{Conclusion and recommendations}

On the basis of different results recorded in the present study it is concluded that sowing onion seeds on $26^{\text {th }}$ October increases Number of leaves, Leaf length, Leaf width, Plant height, Bulb Diameter, Number Bulbs $\mathrm{kg}^{-1}$, Average bulb Weight, and Yield ton $\mathrm{ha}^{-1}$ of onion and the application of $120 \mathrm{~kg}$ $\mathrm{ha}^{-1}$ phosphorus also increases the above parameters at time of transplanting. On the basis of results recorded the following recommendations can be given:

For obtaining maximum yield and larger bulb size, onion should be sown on $26^{\text {th }}$ October provided with phosphorus level of $90 \mathrm{~kg} \mathrm{ha}^{-1}$.

\section{Authors' contributions}

Conceived and designed the experiments: A Rab, Performed the experiments: J Ali, H Mohammad, M Ali, A Rashid \& A Khan Analyzed the data: A Shakoor \& J Khan, Contributed reagents/materials/analysis tools: A Jamal \& H Khan, Wrote the paper: J Ali.

\section{References}

1. Shaheen AM, Abdel-Mouty MM, Aisha A, Ali H \& Rizk FA (2007). Natural and Chemical Phosphorus Fertilizers as Affected Onion Plant Growth, Bulbs Yield and its Some Physical and Chemical Properties. Australian Journal of Basic and Applied Sciences 1(4): 519524.

2. FAO. Food and Agriculture Organization of the United Nation. http://www.fao.org/ (05-10-2011).

3. Singh, Kumar, JVA \& Singh C (2000). Influence of phosphorus on growth and yield of onion (Allium cepa L.). Indian $J$ Agric 34(1): 51-54.

4. Abdissa Y, Tekalign $\mathrm{T} \&$ Plant LM (2011). Growth, bulb yield and quality of onion (Allium cepa L.) as influenced by nitrogen and phosphorus fertilization on vertisol $I$. Growth attributes biomass production and bulb yield. African Journal of Agricultural Research 6(14): 3252-3258.

5. Steel RGD \& Torrie JH (1997). Analysis of covariance, In: Principles and procedures of statistics: a biometrical Approach, McGraw-Hill, New York. pp. 401-437

6. Cheema KL, Saeed A \& Habib M (2003). Effect of Sowing Date on Set Size in Various Cultivars of Onion (Allium cepa L.) Int J Agri Biol 5(2).

7. Galmarini CR \& Gaspera PG (Della) (1995). Effects of transplanting dates and planting density on yield responses on 
onion (Valenciana type). HorticultureArgentina 14(37): 23-29

8. Salam A, M AA \& Hamaiel AF 2004. Effect of Planting Dates and Compounded Fertilizers on Growth, Yield and Quality of Hassawi Onion Under Al-Hassa Oasis Conditions. Scientific Journal of King Faisal University 5(1): 1425.

9. Khan, NR, Ansari AH, Rajput LS, Oad FC \& Sohu GN (2001). Onion response to applied N, P and K fertilizers. Pak J of App Sci 1(3): 369-370.

10. Kiad A (2005). Effect of different sowing methods on yield and bulb characteristics in (Allium cepa) .ISSN, 0283-0161. 169-174.

11. Horneck DA (1999). Function of Phosphorus in plants. Better crop, (83): 6-7.

12. Ghaffor, Jilani AM, Khaliq G \& Waseem K (2003). Effect of NPK levels on the growth and yield of three Onion (Allium cepa L.) verities. Asian $J$ of Plant Sci 2(3): 342-346.

13. Khodadadi M (2012). The effects of planting date and mother bulb size on quantitative and qualitative seed traits of onion red variety. International $J$ of Agri 2(4): 324-327.

14. Singh DP \& Singh RP (1975). Studies on the effect of time of sowing and age of seedling on growth and yield of onion (Allium cepa L.) Ind $J$ Hort 31: 69-73.

15. Turkoglu N, Alp S \& Cig A (2008). Effect of Diamonium Phosphate (DAP) fertilization in different doses on bulb and flower of Narcissus. AmericanEurasian. J Agric \& Environ Sci 4(5): 595-598.

16. Qasem JR (2006). Responses of onion weed and competition duration, and planting times in the central Jordan valley, $J$ of weed Biology and management 6(4): 212-220.

17. Arian A, Khushk A, Baloch A \& Ahmad N (2004). Growth and yielding behaviour of onion in response to essential nutrients. Pakistan J Agric 18(1), 2004

18. Tesfaye B (2009). Effect of Phosphorus Nutrition on growth of Potato Genotypes with constricting Phosphorus efficiency. African Crop Science Journal 17(4): 199-212.

19. Anisuzzaman M, Ashrafuzzaman M, RaziIsmail M, Uddin MK \& Rahim MA (2009). Planting Time and Mulching effect on onion development and seed production. African Journal of Biotechnology 8(3): 412-416. 